\title{
AGE-RELATED HISTOCHEMICAL INVESTIGATIONS OF SMALL INTESTINAL GOBLET CELLS IN BRONZE TURKEYS (MELEAGRIS GALLOPAVO GALLOPAVO)
}

\author{
D. YOVCHEV \& G. PENCHEV
}

Department of Veterinary Anatomy, Histology and Embryology, Faculty of Veterinary Medicine, Trakia University, Stara Zagora, Bulgaria

\begin{abstract}
Summary
Yovchev, D. \& G. Penchev, 2021. Age-related histochemical investigations of small intestinal goblet cells in bronze turkeys (Meleagris gallopavo gallopavo). Bulg. J. Vet. Med., 24, No 2, 176-183.

The aim of the study was to investigate the goblet cell types and their density in the small intestine of bronze turkey (Meleagris meleagris gallopovo), by means of Alcian blue-PAS staining. Sixty birds from 10 age groups were used. In the duodenum and jejunum, goblet cells produced acid, neutral and mixed mucins, while in the jejunum - acid mucins. A negative relationship was observed between cell density and either duodenum or jejunum lengths; such a correlation was not established in the ileum.
\end{abstract}

Key words: bronze turkey, goblet cells, histochemistry, small intestine

\section{INTRODUCTION}

The rate of development of enterocytes in broiler chickens is a key factor of productive performance in broiler chickens, associated with digestive physiology. The small intestinal epithelium is the site where the utilisation and absorption of nutrients occur. It is made of constantly renewing cells located in the areas of crypts, from which derive enterocytes and goblet cells. The latter migrate on intestinal villi and undergo functional alterations (Uni, 2006).

Goblet cells in the gut of mammals and birds, including turkeys, are an important element of non-specific immunity in intestinal infections. The function of these cells is influenced by the morphological intactness of intestinal mucosa (Solis et al., 2007; Kim \& Khan, 2013).

According to Osho et al. (2016), the jejunal mucosa of turkey poults produces only acid mucins. This specific feature is related to biological defense function of the jejunal mucous layer with respect to bacterial agents.

In the small intestine of rodents and broiler chickens, the epithelium is lined with a mucous later. This layer acts as a protective barrier and at the same time, facilitates the transportation of nutrients in 
epithelial cells (Gaudier \& Hoebler, 2006; Uni, 2006; Pelaseyed et al., 2014).

The mucous layer in broiler chickens comprises mainly glycoproteins produced by mucus-secreting goblet cells. The other mucous layer components are water, serum derivatives, cell macromolecules, electrolytes, microorganisms and desquamated epithelial cells. This layer is a component of non-specific immune response and protects the intestinal mucosa from mechanical damage (Apajalahti, 2005; Smirnov et al., 2004; 2005; 2006).

Ding et al. (2011) investigated the density of small intestinal goblet cells in Muscovy ducks. The cells were divided into two types: Alcian-blue positive and PAS-positive. At hatch, their density was the same in all three small intestinal segments. As age advanced, their concentration decreased in the duodenum and jejunum, and was the highest in the ileum. The Alcian blue-positive to PAS-positive cells ratio was substantially reduced until the $9^{\text {th }}$ day post hatch.

According to Uni et al. (2003) and Smirnov et al. (2004), goblet (mucinproducing) cells were present in the small intestine of broiler chickens and turkey poults during the embryonic development until the $7^{\text {th }}$ day post hatch. The number of these cells increased from the duodenum to the ileum. Their development began during the late embryonic period and continued to the post hatching period..

Some researchers affirm that acid mucins were predominant in the intestinal tract mucus of broiler chickens. Sulfated acid mucins are found mainly in the large intestine. The changed chemical composition of mucins in the intestinal tract is a marker of pathological changes (Sheahan \& Jervis, 1976; Shehata et al., 1981).

Published data are mainly on histochemical features of the intestinal tract in broiler chickens and ducks. There are only scarce or inconsistent data on the histochemical features of the duodenum, jejunum and ileum in bronze turkeys. The aim of the present study was to differentiate the goblet cells types according to the chemical composition of their secretion as well as their density and distribution in the small intestinal compartments of bronze turkeys with regard to the age.

\section{MATERIALS AND METHODS}

For the study, 60 clinically healthy bronze turkeys (30 females and 30 males) purchased from state hunting enterprise Mazalat, were used. The birds were reared in an aviary. They were divided into 10 age groups (at 1, 7, 13, 28, 35, 49, 56, 90. 120 and 240 days of age). Each group consisted of 3 male and 3 female turkeys. The experiments were carried out in strict compliance with the rules of the Ethical Committee to the Trakia University, Stara Zagora.

The working protocol was as followed. Eighteen tissue samples ( 3 from the middle of each small intestinal segments) of the respective age group were used to prepare permanent histological preparations. Tissue samples were fixed in $10 \%$ formalin (Merck KGaA, Darmstadt, Germany). After the fixation, they were washed in running water, dehydrated in an ascending ethanol series, cleared in xylene and embedded in paraffin. Cross sections 5 to $6 \mu \mathrm{m}$ were cut on rotational microtome YD-335A (J. Y. M. A. Ltd., China). They were stained after double deparaffinisation in xylene and rehydration in a descending ethanol series using a Alcian blue-PAS commercial staining kit (Merck KGaA Darmstadt, Germany). The staining technique was as followed: Alcian blue solution application $(\mathrm{pH} 2.5)-5$ min; 
Age-related histochemical investigations of small intestinal goblet cells in bronze turkeys ...

rinsing in running water - $3 \mathrm{~min}$; rinsing in distilled water; periodic acid solution application for $10 \mathrm{~min}$; rinsing in running water - $3 \mathrm{~min}$; rinsing in distilled water; Schiff's solution application - $15 \mathrm{~min}$; rinsing in running water $-3 \mathrm{~min}$; rinsing in distilled water; staining with haematoxylin Gill III for $20 \mathrm{~s}$; rinsing in running water - $3 \mathrm{~min}$. Preparations were dehydrated in an ascending ethanol series, cleared with xylene and mounted in Entellan (Carson, 1997; Kiernan, 2008).

Preparations were observed with a Leica DM 1000 light microscope and results: documented with Leica DPC 290 digital camera. Data were processed with LAS V 410.02016 software.

Histochemical differentiation of goblet cells was done according to chemical composition of mucins. Cells containing acid mucins were $\mathrm{AB}+$, neutral mucins: $\mathrm{PAS}+$, and those producing mixed mucins - AB/PAS+.

Histochemical interpretation of results was done according to Nomina Histologica Veterinaria (2017).

Density of goblet cells containing acid, neutral and mixed mucins was calculated as number of cells per $1 \mathrm{~mm}^{2}$ of intestinal villous area (Bogucka et al., 2016). The proportions of the three goblet cell types in the duodenum, jejunum and ileum were calculated.

Results were processed with SPSS 17.5 statistical software. Goblet cell density and proportions of cells containing acid, neutral and mixed mucins were presented as mean and SEM. Multifactorial ANOVA was used to compare the values among the different age groups and t-test: for tissue samples within an age group. Pearson's correlation analysis was used for evaluation of relationship between studied parameters (Arhipova et al., 2003; Duritis et al., 2013).

\section{RESULTS}

\section{Duodenum}

Goblet cells were found out among the enterocytes lining the intestinal villi and crypts. Their nuclei were situated at the base.

On the first day post hatch, goblet cells producing neutral and acid mucins were clearly visible among the enterocytes. Single cells containing mixed mucins were identified. Intestinal crypts were not distinct and goblet cells were distributed on intestinal villi (Fig. 1).

During the next age period (7 days of age), goblet cells assumed their specific elongated shape. They produced both neutral and acid mucins. Compared to the previous age period, the number of goblet cells producing mixed mucins has increased (Fig. 2).



Fig. 1. Duodenum of a bronze turkey, 1 day of age: 1 . intestinal villus; 2 . intestinal epithelium; 3. goblet cells producing mixed mucins; 4. goblet cells producing neutral mucins; 5 . goblet cells producing acid mucins. AB/PAS, bar $=100 \mu \mathrm{m}$.

In the later age periods $(28,56,120$ and 240 days of age), goblet cells demonstrated the features already described in 
previous age groups. The cells were located among intestinal mucous enterocytes, their shape was oval and the nucleus was located in the basal part. Cells producing the three mucin types - acid,

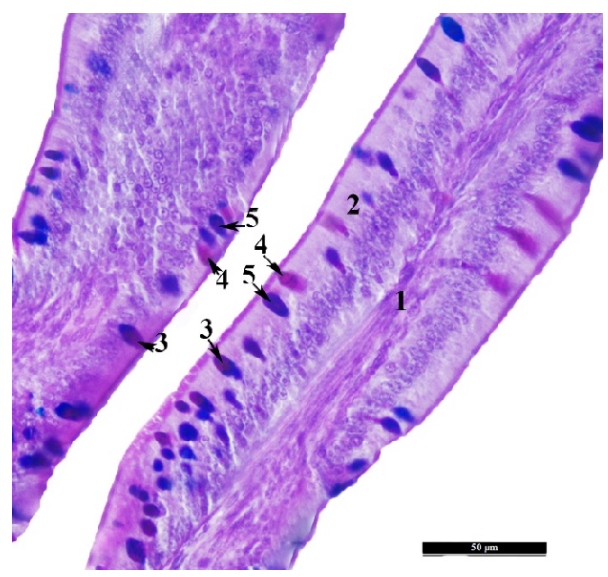

Fig. 2. Duodenum of a bronze turkey, 7 days of age: 1 . intestinal villus; 2 . intestinal epithelium; 3. goblet cells producing mixed mucins; 4. goblet cells producing neutral mucins; 5 . goblet cells producing acid mucins. AB/PAS, bar $=50 \mu \mathrm{m}$.

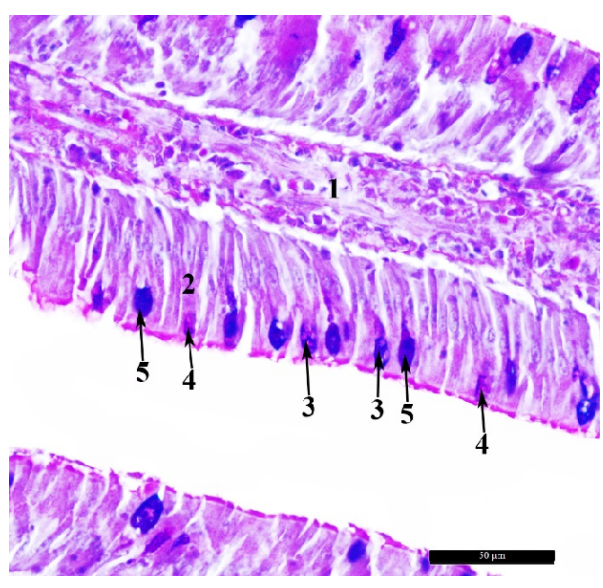

Fig. 3. Duodenum of a bronze turkey, 28 days of age: 1 . intestinal villus; 2 . intestinal epithelium; 3. goblet cells producing mixed mucins; 4. goblet cells producing neutral mucins; 5 . goblet cells producing acid mucins. AB/PAS, bar $=50 \mu \mathrm{m}$. neutral and mixed - were present. The intestinal crypts were well shaped mucosal structures (Fig. 3).

\section{Jejunum}

On the first day of life, goblet cells with specific oval shape were present among jejunal enterocytes. Two types of secretory cells were identified with respect to the chemical composition of mucins they contained - acid and neutral. Intestinal crypts were not well discriminated (Fig. 4).

In the jejunums of bronze turkeys from the other age groups (post hatch days 7 , 14, 28, 56, 120 and 240), goblet cells producing acid, neutral and mixed mucins were found out. They were observed along the intestinal villi and in intestinal crypts. The shape of cells was both strongly elongated with a narrow basal part, as well as oval (Fig. 5 ).

Ileum

From hatch to 240 days of age, only one type of goblet cells was found out in the ileum - cells producing acid mucins. These cells were located along the length of villi and crypts. Under light microsco-

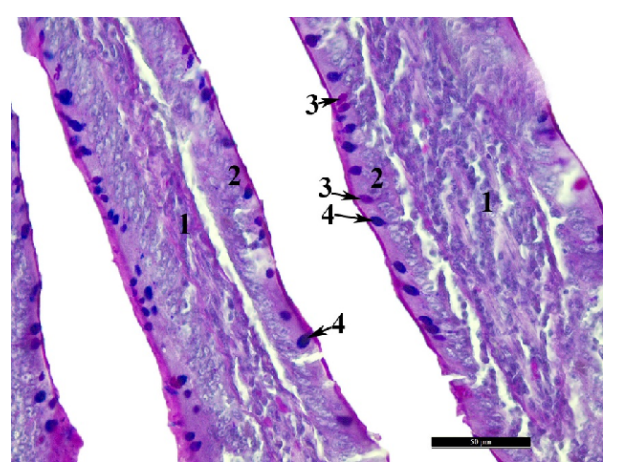

Fig. 4. Jejunum of a bronze turkey, 1 day of age: 1 . intestinal villus; 2 . intestinal epithelium; 3 . goblet cells producing neutral mucins; 4. goblet cells producing acid mucins. $\mathrm{AB} /$ PAS, bar $=50 \mu \mathrm{m}$. 
Age-related histochemical investigations of small intestinal goblet cells in bronze turkeys ...

scope, the intestinal crypts appeared as distinct structures of the intestinal mucosa (Fig. 6).

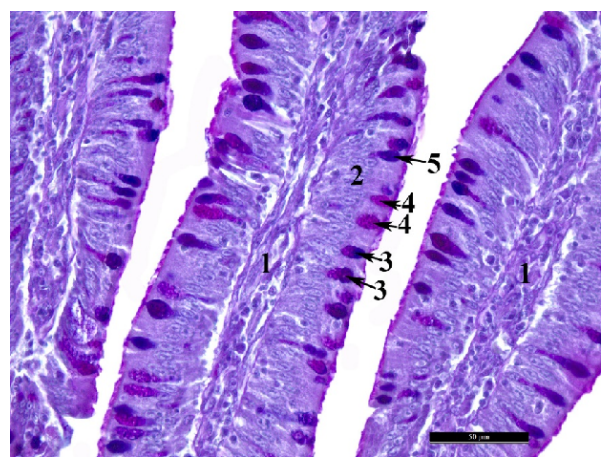

Fig. 5. Jejunum of a bronze turkey, 7 days of age: 1 . intestinal villus; 2 . intestinal epithelium; 3. goblet cells producing mixed mucins; 4. goblet cells producing neutral mucins; 5 . goblet cells producing acid mucins. AB/PAS, bar $=50 \mu \mathrm{m}$.

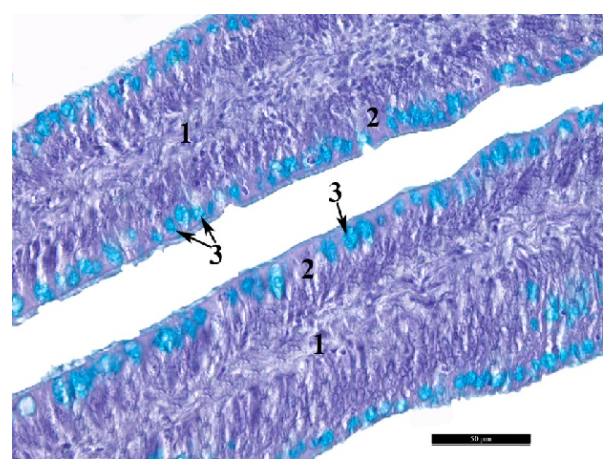

Fig. 6. Ileum of a bronze turkey, 56 days of age: 1. intestinal villus; 2 . intestinal epithelium; 3. goblet cells producing acid mucins. $\mathrm{AB} / \mathrm{PAS}$, bar $=50 \mu \mathrm{m}$.

The goblet cell density in the mucosa of the duodenum, jejunum and ileum was counted per $1 \mathrm{~mm}^{2}$ area from the longitudinal section of intestinal villi.

Age-related goblet cells density in the different small intestinal segments of birds decreased from the $1^{\text {st }}$ to the $240^{\text {th }}$ day of life at a different extent. During the first seven days of life, goblet cell density in the duodenum varied from $960 \pm 38.7$ (post hatch day 1) to $601 \pm 26.4$ (post hatch day 7 ). After the $7^{\text {th }}$ day, the number of goblet cells per $1 \mathrm{~mm}^{2}$ mucosa decreased relatively rapidly $(\mathrm{P}<0.01)$ to attain $376 \pm 11.3$ by post hatch day 56. At 90, 120 and 240 days of age, respective counts were $297 \pm 12.5,250 \pm 13.4$ and $168 \pm 9.8$.

A similar tendency was observed in the jejunum, where the goblet cell density decreased insignificantly until the $28^{\text {th }}$ day of life; these changes were most pronounced from post hatch days 7 to 28 $(\mathrm{P}<0.05)$. By the $28^{\text {th }}$ day, average jejunal goblet cell density was $97 \pm 9.1$ and tended to increase to 56 days of age when it reached $130 \pm 18.7$ per $1 \mathrm{~mm}^{2}$. Afterwards, detected average density was $110 \pm 10.8$, $103 \pm 9.5$ and $98 \pm 9.9$ at 90,12 and 240 days of age respectively.

The ileum also showed a tendency towards reduction of goblet cell density from the first $(2367 \pm 135)$ to the $14^{\text {th }}$ day post hatch $(462 \pm 31.5)$. In the subsequent age groups, it increased to attain the peak value of $820 \pm 145.2$ by the $56^{\text {th }}$ day. Afterwards, counts were as followed: $680 \pm$ 38.8 (day 90), $705 \pm 37.4$ (day 120), $714 \pm$ 38.6 (day 240) (Table 1).

Goblet cells' density correlated negatively with duodenum and jejunum lengths $(\mathrm{r}>-0.5 ; \mathrm{P}<0.01)$ e.g. their number decreased as intestines grew. Such negative correlation was not found out in the ileum.

During the entire study period, goblet cells producing acid $(\mathrm{AB}+)$ and mixed $(\mathrm{AB} / \mathrm{PAS}+)$ mucins prevailed in the duodenum and the jejunum. At the same time, the density of cells producing neutral (PAS+) mucins was statistically significantly lower in both segments $(\mathrm{P}<0.05)$. In the ileum, only goblet cells producing acid mucins $(\mathrm{AB}+)$ were found out. 
Table 1. Goblet cell density in small intestinal mucosa of bronze turkeys from the $1^{\text {st }}$ to the $240^{\text {th }}$ day of age (mean \pm SEM, $\mathrm{n}=18$ ).

\begin{tabular}{clcc}
\hline \multirow{2}{*}{ Age, days } & \multicolumn{3}{c}{ Segment of the small intestine } \\
\cline { 2 - 4 } & Duodenum & Jejunum & Ileum \\
\hline 1 & $960 \pm 38.7$ & $131 \pm 20.8$ & $980 \pm 140.5$ \\
7 & $601 \pm 26.4$ & $124 \pm 15.7$ & $785 \pm 115.5$ \\
14 & $550 \pm 15.7$ & $115 \pm 18.9$ & $462 \pm 91.5$ \\
28 & $480 \pm 20.8$ & $97 \pm 9.1$ & $518 \pm 87.3$ \\
56 & $376 \pm 11.3$ & $130 \pm 18.7$ & $820 \pm 145.2$ \\
90 & $297 \pm 12.5$ & $110 \pm 10.8$ & $680 \pm 38.8$ \\
120 & $250 \pm 13.4$ & $103 \pm 9.5$ & $705 \pm 37.4$ \\
240 & $168 \pm 9.8$ & $98 \pm 9.9$ & $714 \pm 38.6$ \\
\hline
\end{tabular}

At hatch, PAS + cells in the duodenum were $11.9 \pm 2.6 \%$ of all goblet cells. Their density was relatively high in the last studied age group: 240 days of age $-25.5 \pm$ $12.7 \%$. During the first 14 days of life, the number of $\mathrm{AB}+$ positive goblet cells increased and reached a peak $(64.3 \pm 13.1 \%)$.

On the day of hatch, both $\mathrm{AB}+$ и PAS + goblet cells were found out in the jejunum. The number of $\mathrm{AB}+$ increased gradually to attain maximum percentage on 7 days of age $(78.3 \pm 14.2 \%)$. On that day, PAS+ cells proportion was $4.5 \pm$ $0.7 \%$, and that of $\mathrm{AB} / \mathrm{PAS}+$ cells $-17.2 \pm$ $4.8 \%$. At 56 days of age, the relative share of $\mathrm{AB}+$ and $\mathrm{AB} / \mathrm{PAS}+$ cells was almost identical: $44.6 \pm 11.8 \%$ and $45.1 \pm 10.2 \%$, for $\mathrm{AB}+$ and $\mathrm{AB} / \mathrm{PAS}+$ cells, respectively. The PAS+ cell percentage was the lowest: $10.3 \pm 1.1 \%$.

In birds from 56 to 240 days of age, the proportion of duodenal and jejunal $\mathrm{AB}+$ goblet cells was lower compared to increased share of PAS + cells. At the same time, the number of $\mathrm{AB} / \mathrm{PAS}+$ cells remained relatively constant.

\section{DISCUSSION}

The results from this histochemical study presented goblet cells as mucinous glands with oval shape, located among intestinal crypts. These data correspond to histochemical features of ostrich small intestine reported by Duritis et al. (2013).

Considering the biological role of small intestinal epithelium in birds for utilisation of nutrients, our study was focused on histochemical features of goblet cells in the three small intestinal segments in bronze turkeys as did Uni (2006) in broiler chickens. It should be noted that cells found out in the duodenum and jejunum produced acid, neutral and mixed mucins whereas in the ileum, goblet cells were only from the type producing acid mucins.

These results of ours allowed proposing another classification of goblet cells in the small intestinal epithelium of bronze turkeys, namely cells producing acid, neutral and mixed mucins. Our interpretation differs from that of Cheng (1974) for same cells in mammals, which have been typed on the basis of location of secretory granules. 
Age-related histochemical investigations of small intestinal goblet cells in bronze turkeys ...

The goblet cells in the small intestine of bronze turkeys were investigated as a key biological factor for mucous layer secretion. This layer is a protective barrier and participates in the absorption of nutrients. Both the types of cells in the three small intestinal segments as well as their age-related distribution are reported. These data add to knowledge about these cells and their primary role for maintaining the intestinal mucosal physiology (Smirnov et al., 2004; 2005; 2006; Pelaseyed et al., 2014).

Similarly to Ding et al. (2011) in Muscovy ducks, this study investigated the goblet cell density in bronze turkey's small intestine. The goblet cell density in the duodenum and jejunum correlated inversely with the length of respective segment, e.g. goblet cell number decreased as the intestine length increased. Such a relationship was not found out in the ileum.

The study experimental design included monitoring of histochemical features and goblet cell density in bronze turkeys from hatch to 240 days of age. Three goblet cell types were demonstrated in the duodenum and jejunum, while in the ileum, goblet cells produced only acid mucins. This specific feature disagrees with data of Uni et al. (2003) and Smirnov et al. (2004), affirming that goblet cells produced only acid and neutral mucins. Our data confirmed that the number of these cells increased from the duodenum to the ileum, thus adding to data described by Uni et al. (2003) and Smirnov et al. (2004).

In our opinion, goblet cells producing acid mucins were encountered in the duodenum, jejunum and ileum, being the only type identified in the latter segment. This fact was not in line with reports for presence of acid mucins only in jejunum and large intestine in turkey poults (Osho et al., 2016) and broiler chickens (Shehata et al., 1981).

\section{ACKNOWLEDGEMENTS}

The present studies were funded by the following scientific projects: НП 01/2011 "Age, weight and morphometric studies of organs from the middle and caudal digestive tract compartments in bronze turkeys " and HП 09/16 „Age-related histological and histomorphometric investigation of small intestine in bronze turkey (Meleagris meleagris gallopovo)".

\section{REFERENCES}

Apajalahti, J., 2005. Comparative gut microflora, metabolic challenges, and potential opportunities. The Journal of Applied Poultry Research, 14, 444-453.

Bogucka, J., A. Dankowiakowska, G. Elminowska-Eenda, A. Sobolewska, A. Szczerba \& M. Bednarczyk, 2016. Effects of prebiotics and synbiotics delivered in ovo on broiler small intestine histomorphology during the first days after hatching. Folia Biologica (Kraków), 64, 131-143.

Carson, F. L., 1997. Histotechnology. Chicago, ASCP Press. p. 304.

Ding, B., A. Pirone, C. Lenzi, X. Nie, A. Baglini \& I. Romboli, 2011. Histochemical features of the Muscovy duck small intestine during development. Tissue and Cell, 43, 190-195.

Duritis, I., A. Mugurevics \& L. Mancevica, 2013. Distribution and characterization of the goblet cells in the ostrich small intestine during the pre-and posthatch period. Veterinarija ir Zootechnika, 85, 23-28.

Gaudier, E. \& Ch. Hoebler, 2006. Rôles physiologiques des mucines dans la barrière colique. Gastroentérologie Clinique et Biologique, 30, 965-974.

Kiernan, J. A., 2008. Histological and Histochemical Methods, $4^{\text {th }}$ edn, Scion Publishing Ltd. p. 606. 
Kim, J. J. \& W. I. Khan, 2013. Goblet cells and mucins: Role in innate defense in enteric infections. Pathogens, 2, 55-70.

Nomina Histologica Veterinaria, 2017. http://www.wava-amav.org/downloads/ NHV_2017.pdf (10 February 2020 date last accessed).

Osho, S. O., T. Wang, N. L. Horn \& O. Adeola, 2017. Comparison of goblet cell staining methods in jejunal mucosa of turkey poults. Poultry Science, 96, 556-559.

Pelaseyed, T., J. H. Bergström, J. K. Gustafsson, A. Ermund, G. M. Birchenough, A. Schütte, S. van der Post, F. Svensson, A. M. Rodríguez-Piñeiro, E. E. Nyström, C. Wising, M. E. Johansson \& G. C. Hansson. 2014. The mucus and mucins of the goblet cells and enterocytes provide the first defense line of the gastrointestinal tract and interact with the immune system. Immunological Reviews, 260, 8-20.

Sheahan, D. G. \& H. R. Jervis, 1976. Comparative histochemistry of gastrointestinal mucosubstances. American Journal of Anatomy, 146, 103-131.

Shehata, A. T., J. Lernr \& D. S. Miller, 1981. Development of brush-border membrane hexose transport system in chick jejunum. American Journal of Physiology, 240, 102-108.

Smirnov, A., D. Sklan \& Z. Uni, 2004. Mucin dynamics in the chicken intestine are altered by starvation. The Journal of Nutrition, 134, 736-742.

Smirnov, A., E. Tako, P. R. Ferket \& Z. Uni, 2006. Mucin gene expression and mucin content in the chicken intestinal goblet cells are affected by in ovo feeding of carbohydrates. Poultry Science, 85, 669-673.

Smirnov, A., R. Perez, E. Amit-Romach, D. Sklan \& Z. Uni, 2005. Mucin dynamics and microbial populations in chicken small intestine are changed by dietary probiotic and antibiotic growth promoter supple- mentation. The Journal of Nutrition, 135 187-192.

Solis, F., A. M. Donoghue, M. B. Farnell, G. R. Huff, W. E. Huff \& D. J. Donoghue, 2007. Gastrointestinal maturation is accelerated in turkey poults supplemented with a mannan-oligosaccharide yeast extract (Alphamune). Poultry Science, 86, 921-930.

Uni, Z., 2006. Early development of small intestinal function. Chapter 3. In: Avian Gut Function in Health and Disease, Poultry Science Symposium Series, vol. 28, ed G. C. Perry, The British Library, London, UK, pp. 29-43.

Uni, Z., A. Smirnov \& D. Sklan, 2003. Preand post-hatch development of goblet cells in the broiler small intestine: Effect of delayed access to feed. Poultry Science, 82, 320-327.

Paper received 03.12.2019; accepted for publication 20.01.2020

\section{Correspondence:}

David Yovchev

Department of Veterinary Anatomy,

Histology and Embryology,

Faculty of Veterinary Medicine, Trakia University, Stara Zagora, Bulgaria, e-mail: davidgospodinovyovchev@gmail.com 